ISSN 1392-3196 / e-ISSN 2335-8947

Zemdirbyste-Agriculture, vol. 104, No. 3 (2017), p. 195-202

DOI $10.13080 / \mathrm{z}-\mathrm{a} .2017 .104 .025$

\title{
The status of soil organic matter decomposing microbiota in afforested and abandoned arable Arenosols
}

\author{
Jūrate ALEINIKOVIENE் ${ }^{1,3}$, Kęstutis ARMOLAITIS ${ }^{1,2}$, Rūta ČESNULEVIČIENE் ${ }^{2}$, \\ Vilma ŽĖKAITÉ ${ }^{2}$, Milda MURAŠKIENË ${ }^{1}$ \\ ${ }^{1}$ Institute of Forestry, Lithuanian Research Centre for Agriculture and Forestry \\ Liepų 1, Girionys, Kaunas distr., Lithuania \\ ${ }^{2}$ Perloja Experimental Station, Lithuanian Research Centre for Agriculture and Forestry \\ Perliaus 40, Perloja, Varena distr., Lithuania \\ ${ }^{3}$ Institute of Agroecosystems and Soil Science, Aleksandras Stulginskis University \\ Studentu 11, Akademija, Kaunas distr., Lithuania \\ E-mail: jurate.aleinikoviene@asu.lt
}

\begin{abstract}
Organic matter decomposing soil microbiota status (abundance and diversity) have been investigated in former arable Arenosols (AR) that (i) were afforested 45 years ago with Scots pine (Pinus sylvestris L.) plantations or (ii) abandoned for the last 12 years (since 1993). The abundance of soil microbiota in soil organic layer (forest floor or dead grass fall) and in surface $0-2$ and 2-10 cm mineral layers of former ploughed Ap horizon was estimated by the standard method of sowing organic or mineral soil suspensions on the agarised nutrient standard media and on media supplemented by mineral substances and different lignin monomers. The diversity of soil microbiota was determined only in surface mineral layers and was expressed according to the occurrence of the cytochrome P450 gene in mineral soil. The highest abundance of soil microbiota was found in organic layers of former arable Arenosols, especially, in forest floor of pine plantations, where mean abundance of microbiota was from 4-10 to even 20-30-fold higher than in surface mineral layers of former arable horizon. However, in the studied surface mineral soil layers mean microbial abundance, including lignin decomposing microbiota, was on average by $2-5$ times higher in abandoned land than in pine plantations. In addition, it was determined that the microbiota diversity was two times higher in abandoned Arenosols where more actinobacteria and proteobacteria strains were, while in 45-year-old pine plantations organic matter decomposers were mainly proteobacteria strain related.

It was concluded that the accumulation and the decomposition of forest floor, and lower abundance and diversity of microbiota in surface mineral layer preserve or even could promote higher sequestration rate of soil organic carbon in afforested than in abandoned arable Arenosols.
\end{abstract}

Key words: abundance and diversity, afforestation or abandonment, arable Arenosols, lignin monomers, organic carbon, soil microbiota.

\section{Introduction}

Forests accumulate large quantities of carbon (C) not only in the biomass of trees and others forest plants but in forest soils as well. Median soil organic carbon (SOC) pool in the mineral soil of European forests is approximately 1.5 times as high as in the trees (De Vries et al., 2006). Meanwhile, the intensive cultivation of agricultural land and the removal of organic carbon (OC) with crop yield could cause a $30-50 \%$ loss of SOC (Virto et al., 2012). Therefore without the compensation of organic matter, like in practice of organic-sustainable farming, the SOC accumulation usually decreases in conventional-chemical farming systems (Fornara, Tilman, 2008; Bakšienè et al., 2014).

The European Parliament Directive on Soil Protection and Improvement (COM (2006) 232) emphasizes that SOC accumulation with the litter

biomass is the key for soil conservation in the sustainable development of agriculture and forestry. Thus, along the carbon accumulation the forests may reduce $\mathrm{CO}_{2}$ concentrations in the atmosphere (Dijkstra et al., 2009).

The natural or artificial afforestation is mostly common in unsuitable for agriculture or in abandoned former arable land. Such afforestation of inappropriate farming and unused state land could be relevant with the focus on carbon sequestration. This is especially important for the European Union countries committed to reduce $\mathrm{CO}_{2}$ emissions following the Kyoto Protocol and reducing the negative effects of the climate change (Feller, Bernoux, 2008).

The afforestation of arable land, especially with coniferous trees, induces chemical changes in mineral topsoil. The accumulation and decomposition of the

Please use the following format when citing the article:

Aleinikovienè J., Armolaitis K., Česnulevičienė R., Žèkaitė V., Muraškienė M. 2017. The status of soil organic matter decomposing microbiota in afforested and abandoned arable Arenosols. Zemdirbyste-Agriculture, 104 (3): 99-106 DOI 10.13080/z-a.2017.104.025 
forest litterfall is influencing the destruction of former ploughed Ap horizon by the leaching of organic $\mathrm{C}$ acids and nutrients (mainly exchangeable cations of potassium, calcium and magnesium) that is indicated by increasing of mineral soil acidity (Lal, 2009). Due to the formation of a thin humus horizon in the surface of mineral soil, carbon stock increases in the surface $0-5 \mathrm{~cm}$ mineral soil layer but decreases in the deeper $(5-25 \mathrm{~cm})$ layer. Therefore, the initial carbon pools in $20-30 \mathrm{~cm}$ thick mineral topsoil tend to decrease during the first 5-10 years following afforestation of arable land. However, in forest plantations older than $30-40$ years, the store of soil carbon has recovered to the original level and starts to increase (Bárcena et al., 2014; Malý et al., 2014). Such an increase is especially considerable in the nutrient-poor sandy soils with a low carbon stock (Armolaitis et al., 2007; Xiong et al., 2014).

The accumulation of SOC significantly depends on the abundance and activity of soil microbiota (Chaudhry et al., 2012; Tkacz et al., 2015). Only a part of OC is stabilized in soil humus or in the soil microbiota biomass. Even though, some studies have emphasized that, as an example, the sandy soils in abandoned agricultural land due to more intensive distribution of precipitation, higher soil temperature, better aeration and lower acidity contribute to a large and more active soil microbiota community if to compare with forest land (Lagomarsino et al., 2012; Müller-Stöver et al., 2012).

In this study we compared the soil microbiota status in nutrient-poor arable Arenosols (i) following afforestation with Scots pine and (ii) following abandonment of fertilized arable soils. Particularly, we focused on valuation of the abundance and diversity of soil microbiota that decompose OC compounds. We hypothesized that slowly degradable lignified organic matter could induce the reduction of soil microbiota abundance. Consequently, higher abundance and diversity of soil microbiota could decrease the sequestration of SOC.

\section{Materials and methods}

Study site. The study was carried out at 2005 in Perloja experiment (hereafter - Perloja experiment) of Perloja Experimental Station of Lithuanian Research Centre for Agriculture and Forestry. The Perloja experiment site (total area $40 \mathrm{ha}$ ) is situated in a flat area (elevation $110 \mathrm{~m})$ in Southern Lithuania $\left(54^{\circ} 10^{\prime} \mathrm{N}, 24^{\circ} 25^{\prime} \mathrm{E}\right)$. The mean annual precipitation of the area is $682 \mathrm{~mm}$, whereas mean annual temperature is $6.2^{\circ} \mathrm{C}$, with a mean January temperature of $-5.4^{\circ} \mathrm{C}$ and a mean July temperature of $18.6^{\circ} \mathrm{C}$. The soil in Perloja experiment site is well-drained Haplic Arenosol (ARh) (WRB, 2014) developed on glaciofluvial sandy deposits from Weichselian glaciation.

In 1960, a long-term Perloja experiment was established in arable land with the aim of comparing the productivity of arable land and arable land afforested with Scots pine (Pinus sylvestris L.). Details on the plots and treatments in the Perloja experiment were provided in Armolaitis et al. (2007). For our study we selected two sites of Perloja experiment: (i) non-fertilized 45-year-old Scots pine plantations and (ii) abandoned former fertilized arable land not cultivated for the last 12 years (since 1993).

The main chemical parameters of Haplic Arenosol in Scots pine plantations and adjacent abandoned former arable land of the Perloja experiment are presented in Table 1. In summary, first of all it could be stated that soil organic horizons as well as surface $0-2$ and $2-10 \mathrm{~cm}$ mineral layers of former ploughed Ap horizon were of higher acidity $\left(\mathrm{pH}_{\mathrm{CaCl}} 3.6-4.7\right)$ in Scots pine plantations than in former arable land $\left(\mathrm{pH}_{\mathrm{CaCl} 2} 5.0-6.0\right)$. Also it was found that significantly higher content of organic carbon (OC) was accumulated in soil organic horizons (as forest floor) of pine plantations. Besides, under the forest floor in thin 0-2 cm deep mineral soil layer, the concentrations of soil organic carbon (SOC) and total nitrogen $(\mathrm{N})$ were on average about 2-3 times higher in pine plantations than in abandoned former arable land. However, mean concentrations of mobile $\mathrm{P}_{2} \mathrm{O}_{5}$ and $\mathrm{K}_{2} \mathrm{O}$ were still higher in surface mineral layers of abandoned formerly fertilized arable land.

Soil sampling and microbiota abundance. The following horizons of organic (O) layer of Arenosol were found and sampled (Cools, De Vos, 2016): OL - litter horizon (containing unaltered annual fall of needles, twigs and small branches, cones and bark in pine plantations and dead grass fall in abandoned arable land), OF - fragmented and/or altered horizon (containing partly decompose forest litter and only the remains of the autumn of the previous year grass cover in abandoned arable land) and $\mathrm{OH}$ - humus horizon (well-decomposed, dark and amorphous organic matter in pine plantations; it was absent in abandoned arable land). These horizons comprised forest floor in pine plantations while OF horizon - grass fall in abandoned land. Composite soil samples $(n=3)$ for analyses of soil microbiota abundance were collected from the $\mathrm{OL}$ and $\mathrm{OF}+\mathrm{OH}$ horizons and from $0-2$ and 2-10 cm deep surface layers of former ploughed Ap horizon in each plot at 10 systematically distributed points along the 20 meters transects. The organic layer was sampled using a $1000 \mathrm{~cm}^{2}$ metallic

Table 1. Mean parameters of Arenosol in Scots pine plantations and adjacent abandoned former arable land of the Perloja experiment (adopted from Armolaitis et al., 2007)

\begin{tabular}{|c|c|c|c|c|c|c|}
\hline Horizon & Biotope & \multirow{2}{*}{$\mathrm{pH}_{\mathrm{CaCl}_{2}}$} & \multirow{2}{*}{$\begin{array}{l}\mathrm{SOC} \\
\mathrm{g} \mathrm{kg}^{-1}\end{array}$} & \multirow{2}{*}{$\begin{array}{c}\mathrm{N} \\
\mathrm{g} \mathrm{kg}^{-1}\end{array}$} & \multirow{2}{*}{$\begin{array}{c}\mathrm{P}_{2} \mathrm{O}_{5} \\
\mathrm{mg} \mathrm{kg}^{-1}\end{array}$} & \multirow{2}{*}{$\begin{array}{c}\mathrm{K}_{2} \mathrm{O} \\
\mathrm{mg} \mathrm{g}^{-1}\end{array}$} \\
\hline \multicolumn{2}{|c|}{ depth } & & & & & \\
\hline \multirow{2}{*}{$\mathrm{OL}$} & plantations & $3.7 \pm 0.2$ & $545.7 \pm 6.0$ & $9.4 \pm 1.1$ & $325 \pm 37$ & $584 \pm 49$ \\
\hline & arable land & $5.6 \pm 0.2$ & $360.6 \pm 17.2$ & $10.9 \pm 0.7$ & $650 \pm 30$ & $2593 \pm 101$ \\
\hline \multirow{2}{*}{$\mathrm{OF}+\mathrm{OH}$} & plantations & $3.6 \pm 0.2$ & $386.7 \pm 26.0$ & $8.1 \pm 1.7$ & $247 \pm 6$ & $384 \pm 5$ \\
\hline & arable land & $5.0 \pm 0.1$ & $252.5 \pm 16.5$ & $9.3 \pm 0.4$ & $660 \pm 35$ & $2815 \pm 142$ \\
\hline \multirow{2}{*}{$\begin{array}{c}\mathrm{Ap} \\
(0-2 \mathrm{~cm})\end{array}$} & plantations & $3.6 \pm 0.2$ & $28.7 \pm 1.6$ & $2.3 \pm 0.2$ & $58 \pm 8$ & $146 \pm 18$ \\
\hline & arable land & $5.5 \pm 0.2$ & $8.4 \pm 1.0$ & $1.3 \pm 0.1$ & $136 \pm 8$ & $179 \pm 4$ \\
\hline \multirow{2}{*}{$\begin{array}{c}\mathrm{Ap} \\
(2-10 \mathrm{~cm})\end{array}$} & plantations & $4.7 \pm 0.4$ & $6.5 \pm 0.3$ & $0.5 \pm 0.1$ & $50 \pm 5$ & $51 \pm 2$ \\
\hline & arable land & $6.0 \pm 0.2$ & $5.7 \pm 0.3$ & $1.0 \pm 0.1$ & $148 \pm 11$ & $114 \pm 4$ \\
\hline
\end{tabular}

Note. OL - litter horizon of organic layer, $\mathrm{OF}+\mathrm{OH}-$ fragmented + humus horizons of organic layer (OH horizon was not found in abandoned arable land), Ap - former ploughed mineral horizon; means $(\mathrm{n}=3) \pm$ standard errors are given; significantly $(p<0.05)$ outstanding parameters are shown in bold. 
circular frame while mineral soil - using metallic auger of $3 \mathrm{~cm}$ diameter.

The abundance of cultivable microbiota was distinguished by the standard method of the sowing of organic or mineral soil suspension on the agarised nutrient medium (Fierer et al., 2007). Although, the sowing of diluted gradually by 10,100 and 1000 times soil solutions was performed using standard media and in addition the modified agarised nutrient media were applied. In total 9 media were used (Table 2). Nutrient media numbered by 5-9 were supplemented with the lignin monomers and the differentiation of lignin decomposing microbiota was performed due to the catabolic responses to the specific lignin monomers.

Table 2. Characteristics of the media for the estimation of microbial abundance in Arenosol in afforested with Scots pine plantations and abandoned arable of Perloja experiment

\begin{tabular}{|c|c|c|}
\hline $\begin{array}{l}\text { Medium } \\
\text { number }\end{array}$ & Medium & Adaptability \\
\hline \multicolumn{3}{|c|}{ I. Standard medium } \\
\hline 1. & $\begin{array}{l}\text { Plate-count agar / } \\
\text { standard methods agar }\end{array}$ & $\begin{array}{l}\text { Total abundance of colony forming microbiota } \\
\text { (bacteria, actinobacteria and micromycetes) }\end{array}$ \\
\hline 2. & Bacteriological agar $(\mathrm{BA})^{2}$ & Total abundance of colony forming bacteria \\
\hline \multicolumn{3}{|c|}{ II. Standard medium of bacteriological agar, supplemented by different mineral substances } \\
\hline 3. & BA and mineral soil solution extract ${ }^{3}$ & $\begin{array}{l}\text { Total abundance of colony forming microbiota } \\
\text { assimilating soil mineral nutrients }\end{array}$ \\
\hline 4. & $\begin{array}{l}\mathrm{BA} \text { and mineral medium } \\
\left(\mathrm{MM} \text {, components of mineral medium: } \mathrm{KH}_{2} \mathrm{PO}_{4}-2.3 \mathrm{~g},\right. \\
\mathrm{Na}_{2} \mathrm{HPO}_{4} \times 12 \mathrm{H}_{2} \mathrm{O}-5.8 \mathrm{mg}, \mathrm{NH}_{4} \mathrm{Cl}-1.0 \mathrm{~g}, \mathrm{NaHCO}_{3}-0.5 \mathrm{mg} \text {, } \\
\mathrm{MgSO}_{4} \times 7 \mathrm{H}_{2} \mathrm{O}-2.000 \mathrm{ml}, \mathrm{CaCl}_{2} \times 2 \mathrm{H}_{2} \mathrm{O}-0.068 \mathrm{ml} \text {, } \\
\mathrm{FeCl}_{3} \times 6 \mathrm{H}_{2} \mathrm{O}-0.511 \mathrm{ml}, \mathrm{C}_{6} \mathrm{H}_{5} \mathrm{O}_{7} \mathrm{Na}_{3} \times 2 \mathrm{H}_{2} \mathrm{O}-0.221 \mathrm{ml} \text {; } \\
\text { components adjusted to } 1000 \mathrm{~mL} \text { of solution with distilled water) }{ }^{2}\end{array}$ & $\begin{array}{l}\text { Total abundance of colony forming microbiota } \\
\text { assimilating mineral enrichments in medium }\end{array}$ \\
\hline \multicolumn{3}{|c|}{ III. Standard medium of bacteriological agar, supplemented by mineral substances and lignin monomers } \\
\hline 5. & BA and MM with $0.1 \%$ m-coumaric acid & Total abundance of colony forming microbiota \\
\hline 6. & BA and MM with $0.1 \%$ cinnamyl alcohol & assimilating specific carbon compounds \\
\hline 7. & BA and MM with $0.1 \%$ caffeic acid & (different lignin monomers) \\
\hline 8. & BA and MM with $0.1 \%$ cinnamic acid & \\
\hline 9. & $\mathrm{BA}$ and $\mathrm{MM}$ with $0.1 \% \mathrm{p}$-coumaric acid & \\
\hline
\end{tabular}

Note. Nutrient media were prepared according to: ${ }^{1}$ Ikeda et al. (2009), ${ }^{2}$ Anderson et al. (2011) and ${ }^{3}$ Chaudhry et al. (2012).

Microbiota plates were incubated at $27^{\circ} \mathrm{C}$. The morphology of the bacteria, actinobacteria and micromycetes colonies was assessed on plates after 5-7 days by the needle strike and the optical microscopy. Then the count of colony forming units (CFU) of the microbiota was estimated and the abundance of microbiota was evaluated for $1 \mathrm{~g}$ of to the constant dry (in $90^{\circ} \mathrm{C}$ ) weight of the soil (Ikeda et al., 2009; van Elsas, Boersma, 2011).

Sampling and microbiota diversity. For analyses of soil microbiota diversity soil samples were collected in Scots pine plantations and abandoned arable land only from $0-10 \mathrm{~cm}$ deep mineral topsoil of the former ploughed Ap horizon. Homogenized soil samples were transferred to an Eppendorf tubes and frozen (at $-80^{\circ} \mathrm{C}$ ) and, thus, the bacteria diversity analyses were done in the Department of Molecular Microbiology and Biotechnology of Vilnius University, Lithuania. Diversity of soil microbiota in the Perloja experiment was estimated according to the sequences of the gene for the cytochrome P450 monooxygenases (hereafter - the cytP450) in the microbiota. The cytP450 are widely distributed in different life forms including prokaryotes (archea and bacteria), lower eukaryotes (fungi and insects) and higher eukaryotes (plants and animals) (Jung et al., 2011). The cytP450 constitute a large superfamily of heme proteins, performing the electron and proton transportations across the cell walls. The main function of the cytP450 is the inducing of the organic substrate degradation through the activation of the oxygen $\mathrm{O}_{2}$ molecule, then the banding one $\mathrm{O}$ atom to the molecule of the organic substrate, and the banding of second $\mathrm{O}$ atom with the hydrogen consequently forming water molecule.
The extraction of bacterial DNA from soil was performed according to the instructions described by Reeve et al. (2010), using $1 \mathrm{~g}$ of the soil from each sample for the enzymatic and chemical destruction of soil sample. The DNA was then purified and precipitated for clear DNA pellets according to the instructions described by Bertrand et al. (2005). The bacterial 16S rRNA gene for cytP450 was amplified with two bacterial $16 \mathrm{~S}$ rRNA primers OxyALK1FR 5'-GTG GGC GGC AAC GAC ACS CAN CGG AA-3' and OxyALK2R 5'-GCA CCG GTG GAT R(G/A)CC RAA CCC AAA3' ("Roth and Metabion", Germany; "Fermentas", Lithuania). The PCR machine Mastercycler Epgradient S PGR ("Eppendorf", Germany) was used for this amplification. The amplification was performed according to the manufacturer's instructions, using Taq-DNA polymerase and primers. The following conditions were applied in the amplification of the $16 \mathrm{~S}$ rRNR genes: $94^{\circ} \mathrm{C}$ for $3 \mathrm{~min}$ followed by 29 cycles of $94^{\circ} \mathrm{C}$ for $1 \mathrm{~min}, 60^{\circ} \mathrm{C}$ for $1 \mathrm{~min}$, $72^{\circ} \mathrm{C}$ for $1 \mathrm{~min}$ and final $10 \mathrm{~min}$ extension at $72^{\circ} \mathrm{C}$.

The amplicons with 350 bp were analysed by electrophoresis on agarose gel with ethidium bromide staining and were evaluated from the gel by adding molecular gene ruler Gene Ruler ${ }^{\mathrm{TM}}$ DNA Ladder Mix ("Fermentas"), according to the manufacturer's instructions. The 16S rRNA gene amplicons obtained were inserted in vector $\mathrm{pTZ}$ 7R/ $/ \mathrm{T}$, Inst/Aclone ${ }^{\mathrm{TM}}$ PCR Product Cloning Kit ("Fermentas"), following the manufacturer's instructions, and were applied for the transformation of Escherichia coli DH5a lines. After cultivating the transformed $E$. coli $\mathrm{DH} 5 \alpha$ clones, plasmids were isolated according to the instructions described by van Elsas and Boersma (2011). 
Determination and comparison of bacterial DNA aminoacid and nucleotide sequences. The $16 \mathrm{~S}$ rRNR fragments inserted into the plasmid were digested with AscI, EcoRI, HindIII, EheI, PstI, BamHI, Bsp68I, SalI, KpnI, XhoI, SmaI, NcoI, NdeI, XbaI, AscI, EheI, Eco47III, Eco147I, Ecl136II and PaeI ("Fermentas"), following the manufacturer's instructions. The reaction products were separated with electrophoresis on agarose gel with ethidium bromide staining. Then $16 \mathrm{~S}$ rRNA fragments were digested using the Perfectprep ${ }^{\circledR}$ Plasmid Mini set ("Eppendorf”) and the oligonucleotide primers: M13/pUC(F)5'GCCAGGGTTTTCCCAGTCACGA-3' and M13/ pUC(R)5'-GAGCGGATAACAATTTCACACAGG-3', following the manufacturer's instructions ("Fermentas"). Representative clones showing unique cytP450 fragment length patterns were selected and sequenced in the Center of Sequencing Department of Molecular Microbiology and Biotechnology of Vilnius University, Lithuania. The nucleotide and amino acid sequences were compared directly to all known sequences deposited in GenBank databases using the basic local alignment search tool (NCBI BLAST). The parsimony phylogenetic trees were constructed by the Neighbour-Joining algorithm, with the model of nucleotide replacement using software $M E G A$ 3.1 with 1.000 bootstrap replicate.

Statistical analysis. The data was structured and Analysed using the softwares Microsoft Excel 2010 and STATISTICA 7.0. Differences in the contrasting treatments were statistically evaluated by analysis of variance $(A N O V A)$. In the case of significant effects, the direction of change and test of significance between
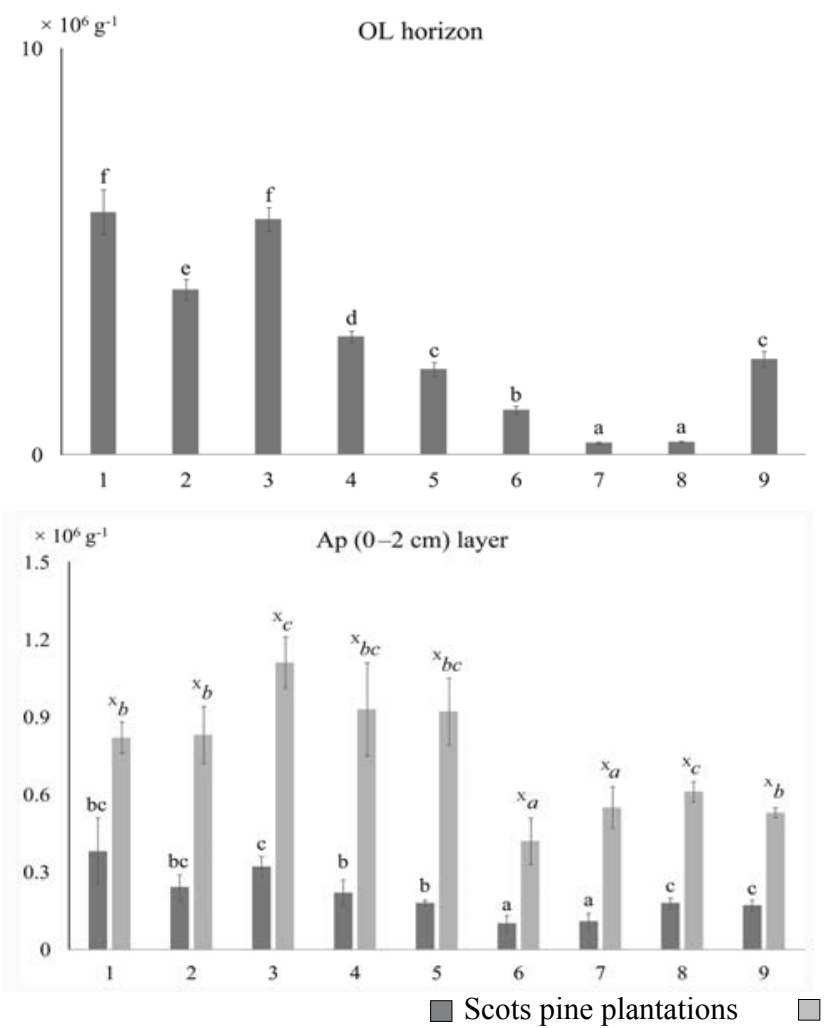

Notes. Means $(\mathrm{n}=9)$ and standard errors (bars) of soil cultivable microbiota abundance evaluated on 1-9 - nutrient media (see Table 2). Asterisks denote significant differences between data obtained in Scots pine plantations and abandoned former arable land $\left({ }^{\mathrm{X}}-p<0.05\right)$. Lower case letters (in Italic for abandoned arable land) denote the significant $(p<0.05)$ differences between nutrient mediums in particular biotope.

Figure. Mean total abundance of microbiota $\left(\times 10^{6} \mathrm{~g}^{-1} \mathrm{CFU}\right)$ in soil organic horizons and in upper mineral layers of Arenosols in Scots pine plantations and abandoned arable land of the Perloja experiment treatment levels were estimated by pairwise $t$-tests. Significant differences in this study are a confidence at the level of $p<0.05$.

\section{Results and discussion}

Abundance of soil microbiota. In the Perloja experiment, the highest mean total abundance of microbiota (bacteria, actinobacteria and micromycetes) was estimated in soil organic (OL and $\mathrm{OF}+\mathrm{OH})$ horizons of abandoned arable land and Scots pine plantations (Fig.). The microbiota in Scots pine forest floor was ranging from 0.29 to 5.79 million $\mathrm{g}^{-1} \mathrm{CFU}(\times$ $\left.10^{6} \mathrm{~g}^{-1} \mathrm{CFU}\right)$. However, the abundance of microbiota in $\mathrm{OF}+\mathrm{OH}$ horizons was more expressed. There the mean total microbiota comprised from $1.23 \times 10^{6} \mathrm{~g}^{-1}$ to 10.29 $\times 10^{6} \mathrm{~g}^{-1} \mathrm{CFU}$ and from $0.02 \times 10^{6} \mathrm{~g}^{-1}$ to $9.62 \times 10^{6} \mathrm{~g}^{-1}$ CFU, respectively, in afforested and abandoned land. In some cases (on 2 and 4 as well as on 6-9 nutrient media), in the $\mathrm{OF}+\mathrm{OH}$ horizons the mean total abundance of cultivable microbota of abandoned arable land was significantly $(p<0.05)$ more than 1.8 times lower than in Scots pine plantations.

The mean total abundance of cultivable microbiota in mineral soil surface layers (up to 0-10 $\mathrm{cm}$ in depth) in abandoned arable land and Scots pine plantations was, respectively, on an average from 4 to 26 times and from 4 to 43 times lower than in soil organic horizons (Fig.). It was estimated that mean abundance of microbiota ranged from $0.45 \times 10^{6} \mathrm{~g}^{-1}$ to $1.11 \times 10^{6}$ $\mathrm{g}^{-1} \mathrm{CFU}$ (in abandoned arable land) and from $0.08 \times$ $10^{6} \mathrm{~g}^{-1}$ to $0.99 \times 10^{6} \mathrm{~g}^{-1} \mathrm{CFU}$ (in Scots pine plantations)
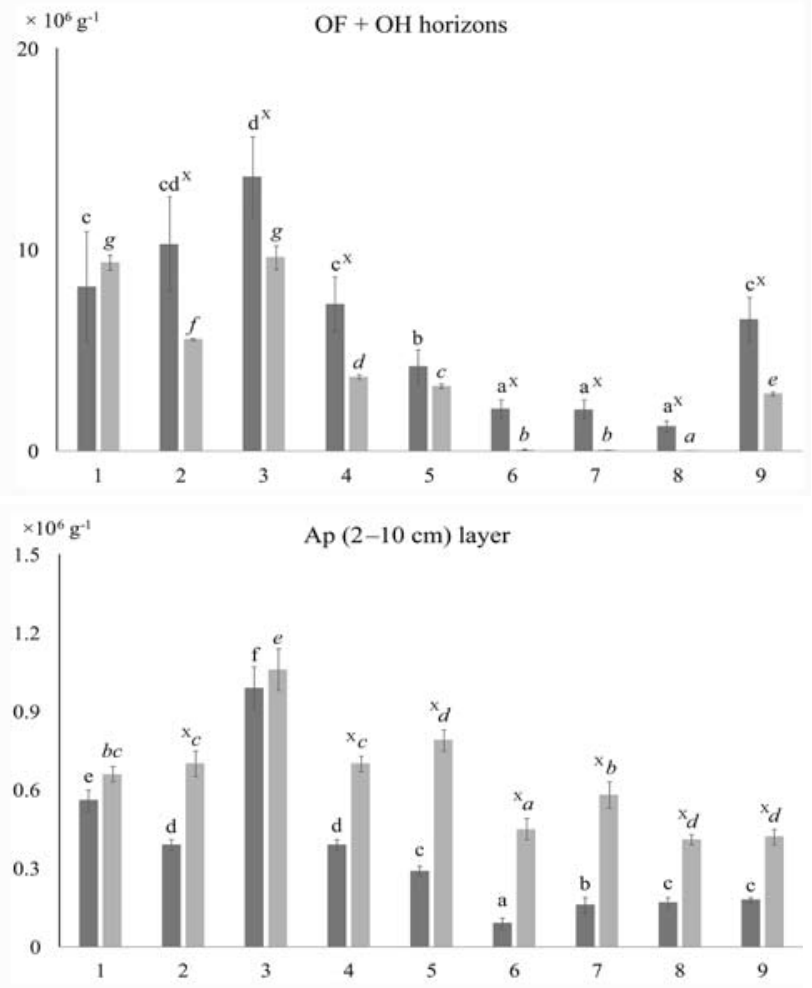

Abandoned arable land 
in $0-2$ and $2-10 \mathrm{~cm}$ mineral soil layers. However, the abundance of cultivable soil microbiota up to $0-10 \mathrm{~cm}$ in depth of mineral soil in abandoned arable land was on average about $2-5$ fold significantly $(p<0.05)$ higher than in Scots pine plantations.

The higher content of easily degradable organic components in organic substrates determines the higher abundance of soil microbiota; meanwhile more lignified organic matter is slowly degradable (Huang et al., 2010). In contrast with OL horizons, where the lignified compounds composition is on average $23-50 \%$, the decomposition of grass litters is faster as the lignified compounds in the biomass compose on average $2-18 \%$ (Kramer et al., 2013). In Perloja experiment, the abundance of lignin decomposing microbiota (on 6-9 nutrient media) in soil organic horizons ranged on average $0.1-4.45 \times 10^{6} \mathrm{~g}^{-1}$ and 1.2-10.1 $\times 10^{6} \mathrm{~g}^{-1} \mathrm{CFU}$, respectively, in abandoned arable land and in Scots pine plantations (Table 2). It is supposed that from 2 to 12 times higher abundance of the microbiota in soil organic horizons could be influenced by the higher accumulation of the lignified compounds in forest floor of Scots pine plantations.

Nevertheless, in mineral soil layers the abundance of microbiota is increasing due to the increase in the content of more available organic carbon (Miltner et al., 2012). Consequently, in Perloja experiment mean abundance of lignin decomposing microbiota in mineral soil layer (up to $0-10 \mathrm{~cm}$ in depth) was about 4 and even 13 fold lower than in organic horizons, respectively, in abandoned arable land and in Scots pine plantations. Even the accumulation of organic carbon in mineral surface layers of the nutrient-poor Arenosol was higher in pine plantations (Table 1), the abundance of lignin decomposing microbiota was on average three fold higher in abandoned land than in Scots pine plantations.
The data on the abundance of soil microbiota have confirmed that due to the complexity of organic material accumulated in the soils, the increase in the abundance of soil microbiota was estimated (Lagomarsino et al., 2012; Trujillo-Cabrera et al., 2013). Thus, the accumulation of forest floor in afforested Arenosol could determine in about two times higher abundance of organic soil microbiota in soil organic horizons of Scots pine plantations than in grass fall of abandoned arable land of Perloja experiment. However, from about 2 to about 5 fold higher abundance of soil microbiota was estimated in mineral soil surface layers of abandoned arable land. As it was mentioned, the higher abundance of microbiota in the abandoned land could have been determined by lower soil acidity, more intense precipitation, and beneficent soil aeration and higher soil temperature (Müller-Stöver et al., 2012; Alluvione et al., 2013).

Taxonomic diversity of soil microbiota. In the microbiota taxonomic classification, the cytochrome P450 monooxygenases are reflective in the differentiation of microbiota on the metabolic demand (Hlavica, 2013). While the microbiota cytP450 might be involved in the degradation of many aromatic compounds including lignin monomers, the prevalence of lignin decomposing bacteria could be estimated (Hungria et al., 2009; Huang et al., 2010). Our studies on soil taxonomic analysis coupled with the standard sequence homology criteria for the cytP450 revealed that the analyzed nucleotide sequences of the clones corresponding to the closest taxonomic homology in the GenBank significantly fell into the Bradyrhizobium, Caulobacter, Rhodococcus and Rhodopseudomonas species phyla (Table 3). According to the nucleotide sequences for the cytP450, in total 50 clones of microbiota were detected in Scots pine plantations and 113 clones in abandoned land.

Table 3. Distribution of the clone nucleotide sequences for the cytP450 from mineral topsoil in Scots pine plantations and abandoned arable land

\begin{tabular}{|c|c|c|c|c|c|}
\hline \multirow{2}{*}{\multicolumn{2}{|c|}{$\begin{array}{l}\text { Gene or species / } \\
\text { code in GeneBank }\end{array}$}} & \multicolumn{2}{|c|}{ Closest taxonomic neighbour $^{2}$} & \multicolumn{2}{|c|}{ Number of clones ${ }^{3}$} \\
\hline & & $\begin{array}{l}\text { type / } \\
\text { class }\end{array}$ & $\begin{array}{l}\text { order / } \\
\text { family }\end{array}$ & $\begin{array}{l}\text { planta- } \\
\text { tions }\end{array}$ & $\begin{array}{l}\text { abandoned } \\
\text { land }\end{array}$ \\
\hline 1. & $\begin{array}{l}\text { Bradyrhizobium japonicum USDA 110/ } \\
\text { NP } 773883 \text { put.cytP450 }\end{array}$ & $\begin{array}{l}\text { Proteobacteria } \\
\text { Alphaproteobacteria }\end{array}$ & $\begin{array}{l}\text { Rhizobiales } \\
\text { Bradyrhizobiaceae }\end{array}$ & 11 & 28 \\
\hline 2. & $\begin{array}{l}\text { Caulobacter crescentus CB } 15 / \text { YP } 783213 \text { / } \\
\text { NP } 418882 \text { cytP } 450 \text { family protein }\end{array}$ & $\begin{array}{l}\text { Proteobacteria } \\
\text { Alphaproteobacteria }\end{array}$ & $\begin{array}{l}\text { Caulobacterales } \\
\text { Caulobacteraceae }\end{array}$ & 5 & 0 \\
\hline 3. & $\begin{array}{l}\text { Rhodococcus } \text { sp. DEE 5316/ } \\
\text { DQ847175 cytP450 CYP153B7 }\end{array}$ & $\begin{array}{l}\text { Actinobacteria } \\
\text { Actinobacteria }\end{array}$ & $\begin{array}{l}\text { Actinomycetales } \\
\text { Nocardiaceae }\end{array}$ & 0 & 15 \\
\hline 4. & $\begin{array}{l}\text { Rhodococcus sp. MOP 100/ } \\
\text { DQ847177 cytP450 CYP153B7 }\end{array}$ & $\begin{array}{l}\text { Actinobacteria } \\
\text { Actinobacteria }\end{array}$ & $\begin{array}{l}\text { Actinomycetales } \\
\text { Nocardiaceae }\end{array}$ & 0 & 15 \\
\hline 5. & $\begin{array}{l}\text { Rhodopseudomonas palustris BisA53/ } \\
\text { CP000463 cytP } 450\end{array}$ & $\begin{array}{l}\text { Proteobacteria } \\
\text { Alphaproteobacteria }\end{array}$ & $\begin{array}{l}\text { Rhizobiales } \\
\text { Bradyrhizobiaceae }\end{array}$ & 29 & 53 \\
\hline 6. & $\begin{array}{l}\text { Rhodopseudomonas palustris Ha A2/ } \\
\text { NC } 007778 \text { cytP450 }\end{array}$ & $\begin{array}{l}\text { Proteobacteria } \\
\text { Alphaproteobacteria }\end{array}$ & $\begin{array}{l}\text { Rhizobiales } \\
\text { Bradyrhizobiaceae }\end{array}$ & 1 & 0 \\
\hline 7. & $\begin{array}{l}\text { Uncultivated bacteria BAE } 47482 \text { cytP } 450 \\
\text { alkane hidroxilase }\end{array}$ & $\begin{array}{l}\text { Uncultivated bacteria } \\
\text { BAE } 47482 \text { cytP } 450 \\
\text { alkane hidroxilase }\end{array}$ & $\begin{array}{l}\text { Uncultivated bacteria } \\
\text { BAE } 47482 \text { cytP450 } \\
\text { alkane hidroxilase }\end{array}$ & 4 & 2 \\
\hline \multicolumn{4}{|c|}{ Total number of clones } & 50 & 113 \\
\hline
\end{tabular}

The majority of the nucleotide sequences of clones from abandoned land displayed the higher similarity to Bradyrhizobium (28 clones), Rhodococcus ( 30 clones) and Rhodopseudomonas (53 clones) (Table 3 ). Then, the nucleotide sequences in Scots pine plantations - to Bradyrhizobium (11 clones), Caulobacter (5 clones) and Rhodopseudomonas (30 clones). In these subclasses the dominant species related to our studied clones of both studied biotopes are proteobacteria of the alpha subclasses. Alphaproteobacteria, Rhodopseudomonas and Bradyrhizobium grow in symbiosis with the plants. For example, Rhodopseudomonas bacteria are degrading biomacromolecules in soil and may fix the nitrogen and implement the denitrification processes (Anderson et al., 2011). Bradyrhizobium bacteria activate the root nodulation in plants for the atmospheric nitrogen fixation. 
Many individuals of the Alphaproteobacteria are used in soil bioremediation due to their ability to degrade the polyaromatic hydrocarbons (Kleber, Johnson, 2010). Therefore, it is worth mentioning that the distribution of Rhodopseudomonas and Bradyrhizobium species were by 1.8 times higher in abandoned land than in Scots pine plantation (Table 3 ).

The cytP450 nucleotide sequences of five clones from mineral topsoil in Scots pine plantations were represented by species (Caulobacter) of the alphaproteobacteries (Table 3), that are distinguished as a worldwide abundant bacteria species in the soils as well as in open water reservoirs (Kleber, Johnson, 2010). It was estimated that Caulobacter is adapted to survive in the environments with a low concentration of nutrients (especially phosphorus). While Caulobacter may decompose different organic compounds, such as, sucrose, amino acids, fatty acids and alcohols, they are used in creation of the enzymes.

The cytP450 nucleotide sequences of the clones representing the Rhodococcus species of the order Actinomycetales are the prevalent organic matter decomposers in soils (Trujillo-Cabrera et al., 2013). Actinomycetales are able to synthesize cellulose and hemicellulose-degrading enzymes, though, to degrade lignin(Baldrian et al., 2011). In many cases, actinomycetes were found in soils that are rich in organic matter; their abundance in cultivated agricultural land depends directly on the soil fertility (Chaudhry et al., 2012). Moreover, the representatives of the uncultivated bacteria (BAE 47482 on the correspondence to cytP450 alkane hidroxilase) were estimated (Table 3 ). The majority of the uncultivated bacteria prevailed in abandoned arable soils of Perloja experiment. However, the involvement of uncultivated bacteria in the lignin decomposition demands could not yet be clearly explained. In addition, the importance of their involvement in biogeochemical lignin conversions and in the degradation of particular lignin compounds was indicated (Kleber, Johnson, 2010).

It could be concluded that soil microbiota of Arenosols in Scots pine plantations and abandoned arable land produced the gene for the cytP450, and there were more than 3000 clones with DNA for the cytP450 obtained. However, in total 199 randomly picked clones displayed convincing homology to the cytP450 genes, with 50 and 113 clones, respectively, in Scots pine plantations and in abandoned arable land. More than $80 \%$ of clones for the cytP450 showed the homology with Bradyrhizobium, Caulobacter, Rhodococcus and Rhodopseudomonas species phyla. Thus, the clones of abandoned arable land formed the trends of homology to actinobacteria and proteobacteria, while the clones of Scots pine plantations - only to proteobacteria. This could be caused by a loss of weakly competitive non-specialized species, to the benefit of highly competitive or narrow niche decomposition specification. According to that, in the Perloja experiment even the clones of abandoned arable land are more diverse, the soil microbiota clones of the Scots pine plantations in some extent show the maturity of the forest soils.

Soil microbiota and organic matter accumulation. In this study however, higher soil microbiota abundance in organic horizons in Scots pine plantations as well as in abandoned arable land was relative due to the diverse formation of studied soil organic horizons (Fig.). Though, soil microbiota also showed the higher specificities, in particular decomposition of lignified organic matter, which could be strongly affected by the afforestation (Cotrufo et al., 2013). However, lower diversity in bacteria communities could lead to an adjustment of the efficiency of carbon use. This was the distinguished outcome in Scots pine plantations and agrees with other studies of this issue (Bruun et al., 2015). In contrast, even though there is an extent in organic matter in abandoned arable land through the $\mathrm{OF}+\mathrm{OH}$ horizons and abundance of bacteria due to less lignified components in organic matter, bacteria could accelerate organic carbon lost. However, soil microbiota abundance also responds to the soil conditions. According to the previous study of Armolaitis et al. (2007) in Perloja experiment the organic horizons in plantations were significantly more acid - by $1.4-1.9 \mathrm{pH}_{\mathrm{CaCl}}$ units (Table 1) and contained higher concentrations of carbon. In this context, our study confirmed that the microbiota of soil organic horizons was more active not in pine plantations but in abandoned land (Fig.).

The evident increase in soil microbiota was observed in $0-2 \mathrm{~cm}$ mineral topsoil in abandoned arable land (Fig.). Moreover, it could be explained by organic substrate availability in abandoned arable land. In contrast, due to more chemical stabilization of organic compounds decomposition in former Ap horizon in pine plantations was more limited. These changes showed that availability of labile carbon source reduce microbial activity (Bouasria et al., 2012; Jangid et al., 2013). The same tendency was obtained by Armolaitis et al. (2007) in Perloja experiment. The significant changes of organic carbon in mineral soil were found in the uppermost 0-2 cm layer of the former Ap horizon, where carbon pools were on average more than three times greater in pine plantations $\left(0.72 \mathrm{~kg} \mathrm{~m}^{-2} \mathrm{C}\right)$ than in abandoned arable land $\left(0.22 \mathrm{~kg} \mathrm{~m}^{-2} \mathrm{C}\right)$. For that, the decrease in organic matter degradation could increase carbon accumulation, while an increase in degradability might result in the depletion of soil carbon (Talbot, Treseder, 2012).

The afforestation of nutrient-poor sandy soils could result in an increase of soil $\mathrm{C}$ stores (Fornara, Tilman, 2008; Vesterdal et al., 2012). As compared with the recently abandoned arable land, carbon pools were considerably greater in pine plantations, mainly because of the accumulation of soil organic horizons (forest floor). Meanwhile, despite the low decomposition rate of soil organic layers, a significant increase in carbon pools was found in a $0-2 \mathrm{~cm}$ surface mineral layer in pine plantations. The reason could be more active soil microbiota as it was also reported by Poeplau and Don (2013). On the other hand, the accumulation and low decomposition rate of forest organic layers result at least in the maintenance of carbon sequestration in the underlying mineral soil horizons. Thus, the preservation of organic carbon does not occur in abandoned formerly arable land.

\section{Conclusion}

Along with the afforestation of arable Arenosol with Scots pine, the plantations were accumulating forest floor (organic OL, OF and $\mathrm{OH}$ horizons), where high abundance of organic compounds decomposing microbiota was obtained. Meanwhile in abandoned arable land grass litter was on average 12 fold lower with twice lower abundance of cultivable microbiota. However, in mineral topsoil (up to $0-10 \mathrm{~cm}$ in depth) mean abundance of cultivable soil microbiota in abandoned land was by 2-5 fold higher than in Scots pine plantations. Even more, the microbiota diversity was two times higher in abandoned Arenosol as more actinobacteria and proteobacteria strains were estimated, while in pine 
plantations organic matter decomposers were mainly proteobacteria strain related. Summarizing the obtained results, it could be emphasized that in afforested arable land the accumulation and decomposition of forest floor and lower abundance and diversity of microbiota preserve or even increase the sequestration rate of soil organic carbon in surface mineral layer to a higher extent than in abandoned arable Arenosol.

\section{Acknowledgements}

The authors greatly thank Prof. Rolandas Meškys and his research team in the Department of Molecular Microbiology and Biotechnology of Vilnius University for assisting in analyses of soil microbiota diversity. This study was financially supported by the research programme "Productivity and sustainability of agricultural and forest soils" implemented by Lithuanian Research Centre for Agricultures and Forestry. We thank anonymous reviewers for their helpful comments and suggestions.

Received 27052016 Accepted 07042017

\section{References}

1. Alluvione F., Fiorentino N., Bertora C., Zavattaro L., Fagnano M., Chiarandà F. Q., Grignani C. 2013. Shortterm crop and soil response to C-friendly strategies in two contrasting environments. Euronean Journal of Agronomy, 45: 114-123. https://doi.org/10.1016/j.eja.2012.09.003

2. Anderson C. R., Condron L. M., Clough T. J., Fiers M., Stewart A., Hill R. A., Sherlock R. R. 2011. Biochar induced soil microbial community change: implications for biogeochemical cycling of carbon, nitrogen and phosphorus. Pedobiologia. 54 (5): 309-320.

https://doi.org/10.1016/j.pedobi.2011.07.005

3. Armolaitis K., Aleinikovienė J., Baniūnienė A., Lubytė J., Žèkaitè V. 2007. Carbon sequestration and nitrogen status in Arenosols following afforestation or following abandonment of arable land. Baltic Forestry, 13 (2): 169-178.

4. Bakšienè E., Ražukas A., Repečkienè J., Titova J. 2014. Influence of different farming systems on the stability of low productivity soil in Southeast Lithuania. ZemdirbysteAgriculture, 101 (2): 115-124. https://doi.org/10.13080/z-a.2014.101.015

5. Baldrian P., Voříšková J., Dobiášová P., Merhautová V., Lisá L., Valášková V. 2011. Production of extracellular enzymes and degradation of biopolymers by saprotrophic microfungi from the unner lavers of forest soil. Plant and Soil. $338(1-2)$ : 111-125. https://doi.org/10.1007/s11104-010-0324-3

6. Bárcena T. G., Kiær L. P., Vesterdal L., Stéfansdóttir H. M., Gundersen P., Sugurdsson B. D. 2014. Soil carbon stock change following afforestation in Northern Europe: a metaanalysis. Global Change Biology, 20: 2393-2405. https://doi.org/10.1111/gcb.12576

7. Bertrand H., Poly F., Lombard N., Nalin R., Vogel T. M., Simonet P. 2005. High molecular weight DNA recovery from soils prerequisite for biotechnological metagenomic library construction. Journal of Microbiological Methods, 62 (1): 1-11. https://doi.org/10.1016/j.mimet.2005.01.003

8. Bouasria A., Mustafa T., De Bello F., Zinger L., Lemperiere G., Geremia R. A., Choler P. 2012. Changes in root-associated microbial communities are determined by species-specific plant growth responses to stress and disturbance. Euronean Journal of Soil Biology, 52: 59-66. https://doi.org/10.1016/j.ejsobi.2012.06.003

9. Bruun T. B., Elberling B., Neergaard A. D., Magid J. 2015. Organic carbon dynamics in different soil types after conversion of forest to agriculture. Land Degradation and Development, 26 (3): 272-283. https://doi.org/10.1002/ldr.2205

10. Chaudhry V., Rehman A., Mishra A., Chauhan P. S., Nautiyal C. S. 2012. Changes in bacterial community structure of agricultural land due to long-term organic and chemical amendments. Microbial Ecology, 64 (2): 450-460. https://doi.org/10.1007/s00248-012-0025-y
11. COM (2006) 232. Proposal for a Directive of the European Parliament and of the Council establishing a framework for the protection of soil and amending Directive 2004/35/EC. Commission of the European Communities.

12. Cools N., De Vos B. 2016. Part X: Sampling and analysis of soil. UNECE ICP Forests Programme Co-ordinating Centre (ed.). Manual on methods and criteria for harmonized sampling, assessment, monitoring and analysis of the effects of air pollution on forests. Thünen Institute of Forest Ecosystems, Eberswalde, Germany, 115 p. $<$ http://www.icpforests.org/Manual.htm>.

13. Cotrufo M. F., Wallenstein M. D., Boot C. M., Denef K., Paul E. 2013. The microbial efficiency-matrix stabilization (MEMS) framework integrates plant litter decomposition with soil organic matter stabilization: do labile plant inputs form stable soil organic matter? Global Change Biology, 19 (4): 988-995. https://doi.org/10.1111/gcb.12113

14. De Vries W. I. M., Reinds G. J., Gundersen P. E. R., Sterba H. 2006. The impact of nitrogen deposition on carbon sequestration in European forests and forest soils. Global Change Biology, 12 (7): 1151-1173. https://doi.org/10.1111/j.1365-2486.2006.01151.x

15. Dijkstra J. P. M., Reinds G. J., Kros H., Berg B., de Vries W. 2009. Modelling soil carbon sequestration of intensively monitored forest plots in Europe by three different approaches. Forest Ecology and Management, 258 (8): 1780-1793. https://doi.org/10.1016/j.foreco.2008.09.011

16. Feller C., Bernoux M. 2008. Historical advances in the study of global terrestrial soil organic carbon sequestration. Waste Management. 28 (4): 734-740. https://doi.org/10.1016/j.wasman.2007.09.022

17. Hierer N., Bradtord M. A., Jackson R. B. 2007. Toward an ecological classification of soil hacteria. Ecology, 88 (6): 1354-1364. https://doi.org/10.1890/05-1839

18. Fornara D. A., 'lilman D. 2008. Plant functional composition influences rates of soil carbon and nitrogen accumulation. Journal of Ecology, 96: 314-322. https://doi.org/10.1111/j.1365-2745.2007.01345.x

19. Hlavica P. 2013. Evaluation of structural teatures in fungal cytochromes $\mathrm{P} 450$ predicted to rule catalytic diversification. Biochimica et Biophysica Acta (BBA): Proteins and Proteomics, 1834 (1): 205-220. https://doi.org/10.1016/j.bbapap.2012.09.012

20. Huang D. L., Zeng G. M., Feng C. L., Hu S., Lai C., Zhao M. H., Liu H. L. 2010. Changes of microbial population structure related to lignin degradation during lignocellulosic waste composting. Bioresource Technology, 101 (11): 4062-4067. https://doi.org/10.1016/j.biortech.2009.12.145

21. Hungria M., Franchini J. C.., Brandão-Junior O., Kaschuk G., Souza R. A. 2009. Soil microbial activity and crop sustainability in a long-term experiment with three soil-tillage and two crop-rotation systems. Applied Soil Ecology, 42 (3): 288-296. https://doi.org/10.1016/j.apsoil.2009.05.005

22. Ikeda S., Kaneko I., Okubo 'I., Kallos L. E., Eda S., Mitsui H., Minamisawa K. 2009. Development of a bacterial cell enrichment method and its application to the community analysis in soybean stems. Microbial Ecology, 58 (4): 703-714. https://doi.org/10.1007/s00248-009-9566-0

23. Jangid K., Whitman W. B., Condron L. M., Turner B. L., Williams M. A. 2013. Soil bacterial community succession during long-term ecosystem develonment. MolecularEcology, 22 (12): 3415-3424. https://doi.org/10.1111/mec.12325

24. Jung C., de Vries S., Schünemann V. 2011. Spectroscopic characterization of cytochrome P450 Compound I. Archives of Biochemistry and Bionhysics, 507 (1): 44-55. https://doi.org/10.1016/j.abb.2010.12.029

25. Kleber M., Johnson M. G. 2010. Advances in understanding the molecular structure of soil organic matter: implications for interactions in the environment. Advances in Agronomy. 106: 77-142. https://doi.org/10.1016/S0065-2113(10)06003-7

26. Kramer S., Marhan S., Haslwimmer H., Kuess L., Kandeler E. 2013. Temporal variation in surface and subsoil abundance and function of the soil microbial community in an arable soil. Soil Biology and Biochemistry, 61: 76-85. https://doi.org/10.1016/j.soilbio.2013.02.006

27. Lagomarsino A., Grego S., Kandeler E. 2012. Soil organic carbon distribution drives microbial activity and functional diversity in particle and aggregate-size fractions. Pedobiologia, 55 (2): 101-110. https://doi.org/10.1016/j.pedobi.2011.12.002 
28. Lal R. 2009. Challenges and opportunities in soil organic matter research. Euronean Journal of Soil Science, 60 (2): 158-169. https://doi.org/10.1111/j.1365-2389.2008.01114.x

29. Malý S., Fiala P., Reininger D., Obdržálková E. 2014. The relationships among microbial parameters and the rate of organic matter mineralization in forest soils, as influenced by forest tyne. Pedobiologia. 57 (4): 235-244. https://doi.org/10.1016/j.pedobi.2014.09.003

30. Miltner A., Bombach P., Schmidt-Brücken B., Kästner M. 2012. SOM genesis: microbial biomass as a significant source. Biogeochemistry, 111 (1-3): 41-55 https://doi.org/10.1007/s10533-011-9658-z

31. Müller-Stöver D., Hauggaard-Nielsen H., Eriksen J., Ambus P., Johansen A. 2012. Microbial biomass, microbial diversity, soil carbon storage, and stability after incubation of soil from grass-clover pastures of different age. Biology and Fertility of Soils. 48 (4): 371-383. https://doi.org/10.1007/s00374-011-0633-6

32. Poeplau C., Don A. 2013. Sensitivity of soil organic carbon stocks and fractions to different land-use changes across Eurone. Geoderma. 192: 189-201. https://doi.org/10.1016/j.geoderma.2012.08.003

33. Reeve J. R., Schadt C. W., Carpenter-Boggs L., Kang S., Zhou J., Reganold J. P. 2010. Effects of soil type and farm management on soil ecological functional genes and microbial activities. The ISME Journal, 4 (9): 1099-1107. https://doi.org/10.1038/ismej.2010.42

34. Talbot J. M., Treseder K. K. 2012. Interactions among lignin, cellulose, and nitrogen drive litter chemistry-decay relationships. Ecology, 93 (2): 345-354. https://doi.org/10.1890/11-0843.1
35. Tkacz A., Cheema J., Chandra G., Grant A., Poole P. S. 2015. Stability and succession of the rhizosphere microbiota depends upon plant type and soil composition. The ISME Journal 9 (11): 2349-2359

https://doi.org/10.1038/ismej.2015.41

36. Trujillo-Cabrera Y., Ponce-Mendoza A., VásquezMurrieta M. S., Rivera-Orduña F. N., Wang E. T. 2013. Diverse cellulolytic bacteria isolated from the high humus, alkaline-saline chinamna soils. Annals of Microbiologv. 63 (2): 779-792. https://doi.org/10.1007/s13213-012-0533-5

37. van Elsas J. D., Boersma F. G. H. 2011. A review of molecular methods to study the microbiota of soil and the mycosphere. European Journal of Soil Biology, 47 (2): 77-87. https://doi.org/10.1016/j.ejsobi.2010.11.010

38. Vesterdal L., Elberling B., Christiansen J. R., Callesen I., Schmidt I. K. 2012. Soil respiration and rates of soil carbon turnover differ among six common European tree species. Forest Ecology and Management, 264: 185-196. https://doi.org/10.1016/j.foreco.2011.10.009

39. Virto I., Barré P., Burlot A., Chenu C. 2012. Carbon input differences as the main factor explaining the variability in soil organic $\mathrm{C}$ storage in no-tilled compared to inversion tilled agrosystems. Biogeochemistry. 108 (1-3): 17-26. https://doi.org/10.1007/s10533-011-9600-4

40. WRB. 2014. World Reference Base for Soil Resources 2014. International soil classification system for naming soils and creating legends for soil maps. World Soil Resources Reports No. 106. FAO, Rome, 191 p.

41. Xiong X., Grunwald S., Myers D. B., Ross C. W., Harris W. G., Comerford N. B. 2014. Interaction effects of climate and land use/land cover change on soil organic carbon sequestration. Science of the Total Environment. 493: 974-982. https://doi.org/10.1016/j.scitotenv.2014.06.088

ISSN 1392-3196 / e-ISSN 2335-8947

Zemdirbyste-Agriculture, vol. 104, No. 3 (2017), p. 195-202

DOI $10.13080 / \mathrm{z}-\mathrm{a} .2017 .104 .025$

\title{
Dirvožemio organines medžiagas skaidančios mikrobiotos būklè apželdintuose ir dirvonuojančiuose ariamuose smèlžemiuose
}

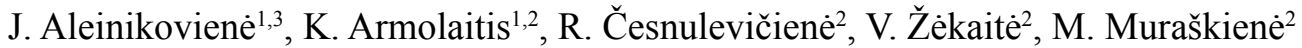 \\ ${ }^{1}$ Lietuvos agrarinių ir miškų mokslų centro Miškų institutas \\ ${ }^{2}$ Lietuvos agrarinių ir miškų mokslų centro Perlojos bandymų stotis \\ ${ }^{3}$ Aleksandro Stulginskio universiteto Agroekosistemų ir dirvožemio mokslų institutas
}

\section{Santrauka}

Organines medžiagas skaidančios dirvožemio mikrobiotos ypatybės (gausumas ir ivvairovė) tirtos artuose smèlžemiuose (SD), kuriuose (i) prieš 45 metus ịveisti paprastosios pušies (Pinus sylvestris L.) želdiniai arba (ii) buvusios žemès ūkio naudmenos dirvonavo 12 metų. Dirvožemio mikrobiotos gausumas vertintas dvieju horizontu - organinių (miško paklotės bei dirvone susiformavusio žolyno apmirusių nuokritų) ir mineralinių (buvusiame artame Ap horizonte) - 0-2 bei 2-10 cm gylio smėlžemiu sluoksnių suspensiju sejjos ant agarizuotu etaloniniu ir papildytų mineralinèmis medžiagomis bei įvairiais lignino monometrais mitybinių terpių metodu. Mikrobiotos įvairovė smėlžemių viršutiniame mineraliniame $0-10 \mathrm{~cm}$ gylio sluoksnyje nustatyta pagal citochromo P450 geno atitikties dažnumą. Didžiausias dirvožemio mikrobiotos gausumas buvo nustatytas artų smėlžemių organiniuose horizontuose ir ypač pušies želdinių miško paklotèje, kur vidutinis mikrobiotos gausumas buvo nuo 4-10 iki net 20-30 kartų didesnis nei dirvožemio viršutiniuose mineraliniuose sluoksniuose. Tačiau dirvonuojančių artų smėlžemiu viršutiniuose mineraliniuose sluoksniuose vidutinis mikrobiotos, taip pat ir ligniną skaidančios mikrobiotos, gausumas buvo vidutiniškai 2-5 kartus didesnis nei pušies želdiniuose. Be to, dirvonuojančiuose smélžemiuose nustatyta du kartus didesnè mikrobiotos ịvairovė, nes juose esanti mikrobiota buvo gimininga aktinobakterijoms ir proteobakterijoms, o 45 metų amžiaus pušies želdiniuose organines medžiagas skaidanti mikrobiota - tik proteobakterijoms.

Apibendrinus tyrimo rezultatus galima teigti, kad dèl miško paklotès kaupimosi bei skaidymosi ir mažesnio mikrobiotos gausumo bei ịvairovès stabilizuota organinès anglies apytaka anglies sekvestravimą skatina daugiau mišku apželdintų ariamų dirvožemių viršutiniuose mineraliniuose sluoksniuose nei dirvonuojančiuose smèlžemiuose.

Reikšminiai žodžiai: apželdinta arba dirvonuojanti žemė, ariami smèlžemiai, dirvožemio mikrobiota, gausumas ir ivvairovè, lignino monomerai, organinè anglis. 